\title{
Development of hollow fiber membranes with alumina and waste of quartzite
}

\author{
Suelem Sonaly Lima Oliveira ${ }^{a, b *}{ }^{\mathbb{D}}$, Sandriely Sonaly Lima Oliveira ${ }^{\circledR}{ }^{\circledR}$, Rodholfo da Silva Barbosa \\ Ferreira $^{b}$, Hélio de Lucena Lira ${ }^{b}$, Lisiane Navarro de Lima Santana ${ }^{b}$, Edcleide Maria Araújo ${ }^{b}$ \\ ${ }^{a}$ Instituto Federal de Minas Gerais - IFMG, R. Érico Veríssimo, 371, Londrina, 33115-390, Santa Luzia, \\ $M G$, Brasil \\ ${ }^{b}$ Departamento de Engenharia de Materiais, Universidade Federal de Campina Grande - UFCG, Av. \\ Aprígio Veloso, 882, Bodocongó, 58429-140, Campina Grande, PB, Brasil
}

Received: February 22, 2019; Revised: April 17, 2019; Accepted: June 02, 2019

\begin{abstract}
The development of ceramic membranes with different geometries and compositions extends the possibilities of industrial applications, inducing advantages in terms of increased permeability, membrane area by volume module and chemical, thermal and mechanical resistance. The use of low-cost raw materials is a trend that has grown in scientific research. The aim of this work is to prepare membranes with hollow fiber geometry from alumina and residue of quartzite, by the technique of immersion precipitation in distilled water from a mixture of ceramic mass with a solution of polyethersulfone and, synthesized in temperatures of $1100^{\circ} \mathrm{C}$ to $1500^{\circ} \mathrm{C}$. The hollow fiber membranes were characterized by chemical analysis, X-ray diffraction, particle size distribution, scanning electron microscopy, apparent porosity, flexural strength and permeated water flow by the membranes. The results indicated that the sintering temperature has direct influence on the formation of the mullite phase, and the properties of apparent porosity and permeate flow. The higher the sintering temperature $\left(1400-1500^{\circ} \mathrm{C}\right)$ increase the formation of the mullite phase, the lower the porosity, as well as the lower the permeate water flow in the membranes. However, there was increase in flexural strength in the hollow fiber membranes with high temperature.
\end{abstract}

Keywords: Hollow fiber membranes, mullite, waste of quartzite, alumina.

\section{Introduction}

The ceramic membranes have attracted significant attention when compared to polymeric membranes due to their properties, with regard to mechanical strength, high chemical resistance, thermal stability, insensitive to swelling and easy to clean ${ }^{1,2}$. Ceramic membranes are suitable for applications involving extreme processes and where longterm stability is required ${ }^{3}$. However, conventional tubular ceramic membranes when compared with the hollow fiber configuration, (surface area up to the volume of $9000 \mathrm{~m}^{2}$ $\left.\mathrm{m}^{3}\right)^{1}$, have a much smaller membrane area, which can make them less competitive.

The phase inversion technique combined with sintering is a method of producing hollow fiber ceramic membranes quite promising. Initially, a suspension of ceramic particles in solvent is prepared with a polymer binder and then, through the phase inversion technique of the binder, via exchange with a non-solvent during spinning, the ceramic particles are immobilized. This method can form membranes with specific morphologies. After this preparation, the calcination and sintering are necessary to remove all the organic precursors of the membrane and to consolidate the membrane structure and the mechanical strength. This method of membranes

*suelem.oliveira@ifmg.edu.br preparation in hollow fiber shape has been used to fabricate membranes from a wide range of ceramics, and even metals ${ }^{4-9}$.

Several ceramic materials have been highlighted in the manufacture of membranes, such as alumina, silica, zirconia and titanium. However, they have a high manufacturing cost, mainly due to the materials that are synthetic, so that they are limited for large-scale applications, thus demanding the research and development of sources of economically viable raw materials ${ }^{10-11}$. Recent studies point to the phase of mullite ceramics as a good alternative in order to reduce the cost of manufacturing, since it can be obtained by economically viable sources and presents properties that ensure good performance in the preparation of ceramic membranes ${ }^{10-15}$.

Recent research points out several forms of mullite sintering, for the development of membranes from minerals that present alumina and/or silica in their compositions ${ }^{10,11,16-18}$. Among the studies addressing mullite sources, it may highlight those in which the authors make use of low-cost raw materials or materials from waste as from the rice husk silica ${ }^{10}$, kaolin residue $^{19}$; kyanite ${ }^{20}$; bauxite ${ }^{13,14}$.

The quartzite is a rock, geologically classified as a metamorphic rock, consisting of more than $80 \%$ of quartz, and is an abundant ore in Brazil. The importance of the rock sector for the Brazilian economy is incontestable, but the waste generated is inadequately disposed in the environment, 
without the prediction of reuse ${ }^{21-25}$. Due to the large volume of waste generated, both fine and coarse particle size, the possibility of applying as raw materials in other industries, is seen as an imminent solution to a set of environmental problems that may arise due to improper disposal of this material. Researchers already use this residue to develop gres porcelain ${ }^{21}$, red ${ }^{22}$ and structural ceramics ${ }^{23}$. Indeed, utilizing this waste to make low-cost ceramic membranes can be a promising alternative to waste reduction and recycling.

The aim of this research is to prepare hollow fiber ceramic membranes from alumina and residue of quartzite (fine), to obtain the mullite phase.

\section{Experimental}

\subsection{Materials}

For this study, it was used the following materials: Alumina powder with an average particle size of $0.4-8.0$ $\mu \mathrm{m}$ [ Imerys Fused Minerals, $\alpha$-phase $>99.6 \%$ ], and waste of quartzite supplied by industry located in Paraíba/Brazil were used as the membrane material. N-Methyl-2-pyrrolidone (NMP, Neon Comercial, purity 99.92\%) was used as a solvent to prepare the initial solution. Polyethersulfone (PES, SOLVAY) and Polyethersulfone (PES, Ultrason, 6020P) was used as polymer and Polyvinylpyrrolidone (PVP Neon Comercial) was used as viscosity enhancer and de-ionized water as non-solvent.

\subsection{Preparation of spinning dispersions}

The quartzite residue was submitted to a beneficiation, consisting of grinding and sieving, using the mill CT-242, Servitech, for 45 minutes, and sieve ABNT 200 (aperture $0.074 \mathrm{~mm}$ ).

The combined phase inversion-based extrusion method and sintering technique was used to prepare hollow fiber membranes. Suspension was prepared by mixing Arlacel P135, Polyethersulfone ( $1 \mathrm{wt} \%)$, in an N-methyl-2-pyrrolidinone (NMP) solvent (7.14 wt\%). Afterwards, the mixture was rolled/milled at $100 \mathrm{rpm}$ for $1 \mathrm{~h}$. Alumina (60 wt $\%$ ) and waste of quartzite (40 wt \%), and polyvinylpyrrolidone (PVP, 8 $\mathrm{wt} \%$ ) were added later as a binder and further rolled $/ \mathrm{milled}$ for another $30 \mathrm{~min}$. Prior to extrusion, the suspension was degassed for $24 \mathrm{~h}$ to remove any entrapped air bubbles.

\subsection{Preparation of hollow fiber membrane}

After degassing, the spinning suspension was subsequently pressurized with nitrogen pressure of 3 Bar and extruded through a tube-in-orifice spinneret (Internal diameter $=1.17$ $\mathrm{mm}$; external diameter $=2.35 \mathrm{~mm}$ ). Distilled water was used as the internal coagulant. The degassed suspension was extruded through a spinneret into distilled water at a constant speed of $250 \mathrm{~mL} / \mathrm{h}$ with bore fluid of $250 \mathrm{~mL} / \mathrm{h}$.
The fiber membrane green bodies passed through a certain airgap distance of $10 \mathrm{~cm}$ were immersed in a water coagulant bath to allow the completion of the phase inversion process. Afterwards, they were dried at room temperature. Finally the hollow fibers were sintered at a target temperature ranging from 1100 to $1500{ }^{\circ} \mathrm{C}$. The temperature was first increased to $500{ }^{\circ} \mathrm{C}$ at a rate of $2{ }^{\circ} \mathrm{C} / \mathrm{min}$ to remove any remaining liquids and held for $1 \mathrm{~h}$ for the removal of organic polymer binder and dispersant. Next, the temperature was further increased to the target temperature at a rate of $5^{\circ} \mathrm{C} / \mathrm{min}$ to consolidate the ceramic membrane, up to the specified final temperature for $1 \mathrm{~h}$.

\subsection{Characterizations of hollow fiber membrane}

The chemical compositions of the raw materials were determined by X-ray fluorescence spectrometry using a Shimadzu EDX 700 equipment; and particle size distribution was per-formed by laser scattering (Malver-Mastersiezer 2000) with a dispersion unit (HYDRO 2000G) at $8000 \mathrm{rpm}$ stirring and ultra-sound. The ceramic hollow fiber membranes were characterized by X-ray diffraction (XRD), using a Shimadzu XRD 6000 equipment, with $\lambda=1.541 \AA$, operating at $40 \mathrm{kV}$ and $30 \mathrm{~mA}$ and scanning angle from 5 to $80^{\circ}$, for analyze the developed crystalline phases. The images from scanning electron microscopy were obtained in SSX 550 Superscan - Shimadzu equipment, for analysis of the cross section. The porosity of the membranes was measured using the Archimedes method. For the flow measurement test with distilled water a bench system with tangential flow, at pressure of 1 bar and room temperature $\left(25^{\circ} \mathrm{C}\right)$, was used.

The flexural strength of the sintered hollow fiber from 1100 to $1500{ }^{\circ} \mathrm{C}$ (three test specimens) was determined by using a three-point bending apparatus with a load cell of $5 \mathrm{kN}$. The hollow fibers were positioned onto a planar base horizontally, and a planar crosshead is lowered down at a speed of $0.5 \mathrm{~mm} /$ min until fracture occurred. The bending strength was measured as follows ${ }^{26}$ :

$$
\sigma_{F}=\frac{8 F L D_{0}}{\pi\left(D_{0}^{4}-D_{i}^{4}\right)}
$$

Where, $\mathrm{F}$ is the force at which the fracture of specimen takes place, L is the span, which was kept at $40.3 \mathrm{~mm}$ and Do and Di are the outer and inner diameter of the hollow fiber, respectively.

\section{Results and Discussion}

The chemical composition of waste of quartzite and alumina (wt.\%) is given in Table 1.

Alumina contains practically aluminum oxide (99.60\%) and a small amount of other components (0.4\%) resulting from contamination during the obtaining process.

The results of chemical analysis of quartzite residues showed that the silica is the main component $(\sim 79 \%)$, followed by alumina $(\sim 12 \%)$. The high levels of $\mathrm{SiO}_{2}$ and $\mathrm{Al}_{2} \mathrm{O}_{3}$ are typical of metamorphic rocks. The silica present in the 
Table 1. Chemical compositions of raw materials (wt $\%)$ : Alumina and waste of quartzite (WQ).

\begin{tabular}{lccccccccc}
\hline & $\mathrm{SiO}_{2}$ & $\mathrm{Al}_{2} \mathrm{O}_{3}$ & $\mathrm{MgO}$ & $\mathrm{K}_{2} \mathrm{O}$ & $\mathrm{Fe}_{2} \mathrm{O}_{3}$ & $\mathrm{CaO}$ & $\mathrm{TiO}_{2}$ & $\mathrm{SO}_{3}$ & Others \\
\hline Alumina & 0.27 & 99.60 & - & - & 0.04 & - & - & - & 0.09 \\
WQ & 79.62 & 12.43 & 0.95 & 4.44 & 1.11 & 0.63 & 0.13 & 0.44 & 0.25 \\
Formulation & 32.34 & 63.56 & 1.54 & 1.52 & 0.49 & 0.28 & - & - & 0.27 \\
\hline
\end{tabular}

WQ - Waste of quartzite.

residues comes from free silica, feldspar and mica. In smaller proportions, there are the melting oxides, usually present in the quartzite residues as impurities in the form of feldspar and micaceous mineral. The $\mathrm{K}_{2} \mathrm{O}$ content $(<4 \%)$, probably is related to the presence of mica and microcline detected in these samples. As for calcium and magnesium oxides, they may be associated with minerals such as dolomite. The low percentage of iron oxide, around $1.0 \%$, is fundamental for the production of white ceramics, because in levels higher than $5 \%$, this oxide can develop reddish color in the ceramic piece during the sintering ${ }^{21-23}$.

Other researchers studied the incorporation of quartzite residues in ceramic masses and in the chemical analysis it were detected contents of silica, alumina and fluxes oxides similar to those found in this work ${ }^{21-24}$.

The results of the chemical analysis of membrane formulation indicated that, the mixture contains $32.35 \%$ of silicon oxide from quartzite residues, $63.56 \%$ of aluminum oxide and $4.1 \%$ formed by other oxides. In general, the chemical analysis indicates that the obtained composition can confer suitable contents of $\mathrm{SiO}_{2}$ and $\mathrm{Al}_{2} \mathrm{O}_{3}$ with potential for the mullite phase formation.

In Figure 1 it was observed the granulometric distribution of the ceramic mass formulation.

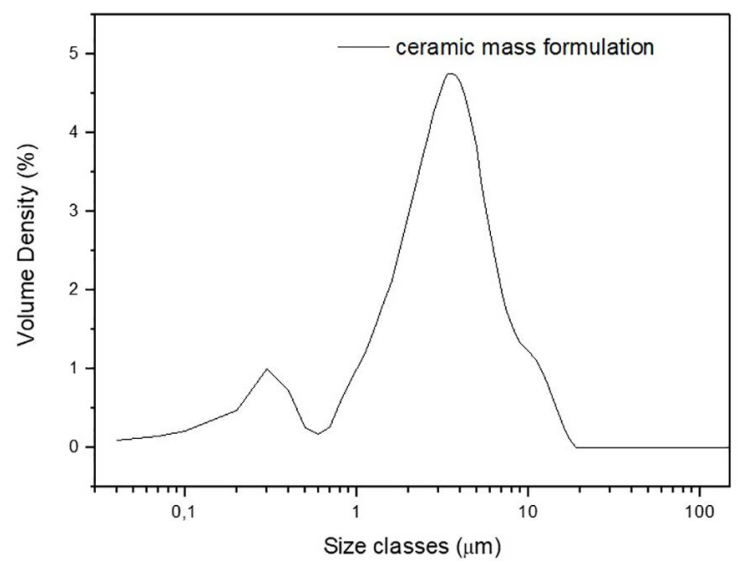

Figure 1. Particle size distribution of the ceramic mass formulation.

The result of the particle size analysis of the ceramic mass formulation, Figure 1, indicates a bimodal behavior, $10 \%$ of the particles have an equivalent diameter of less than $0.9 \mu \mathrm{m} ; 50 \%$ below $3.69 \mu \mathrm{m}$ and $90 \%$ of the particles below $18.30 \mu \mathrm{m}$; the equivalent mean diameter was 2.85 $\mu \mathrm{m}$. The narrower the distribution presented by the curve of particle diameter, the greater homogeneity in terms of the distribution, geometry and pore size of the membrane ${ }^{27}$. Considering that the presented distribution is narrow, it is expected that the membranes distribution, size and geometry of pores are suitable for the separation processes.

The Figure 2 illustrates the results from $\mathrm{X}$-ray diffraction of the membranes sintered at $1100{ }^{\circ} \mathrm{C}, 1200^{\circ} \mathrm{C}, 1300{ }^{\circ} \mathrm{C}$, $1400{ }^{\circ} \mathrm{C}$ and $1500{ }^{\circ} \mathrm{C}$.

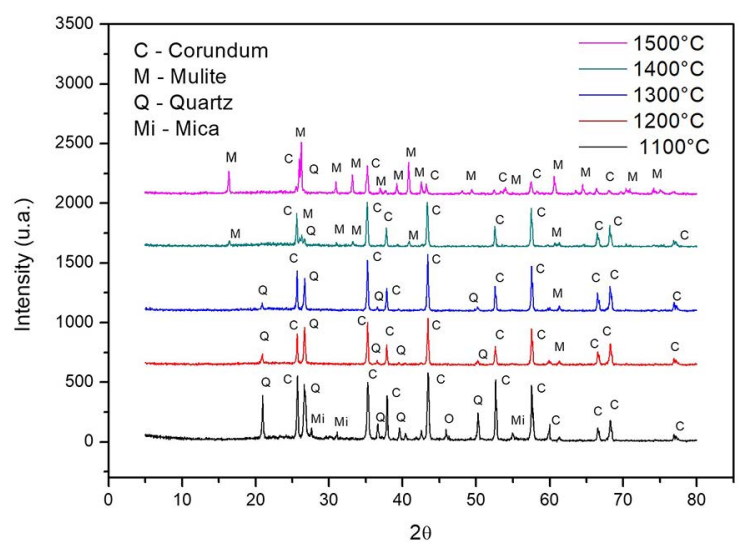

Figure 2. XRD analysis of hollow fiber membranes from alumina and waste quartzite sintered at $1100{ }^{\circ} \mathrm{C}, 1200{ }^{\circ} \mathrm{C}, 1300{ }^{\circ} \mathrm{C}, 1400$ ${ }^{\circ} \mathrm{C}$ and $1500{ }^{\circ} \mathrm{C}$.

From the X-rays diffraction curves of the hollow fiber membranes, Figure 2, it can be identified that, in general, the main characteristic peaks were: mullite (JCPDS: 79-1276), corundum (JCPDS: 10-0173) and quartz (JCPDS: 46-1045). Only for $1100^{\circ} \mathrm{C}$ appeared the peak of mica (JCPDS 83-1808). The formation of these peaks corroborates with the chemical analysis and composition of suspension used for membrane formation, including residue of quartzite and alumina.

Increased sintering temperature of the membranes from 1100 ${ }^{\circ} \mathrm{C}$ to $1200{ }^{\circ} \mathrm{C}$ generated the disappearance of the crystalline phase of mica, due to the fluxes oxides, and also a decrease in the intensity of the corundum and quartz peaks, and appearance of the peaks characteristic of the mullite phase with low intensity.

According to the X-ray diffractions results, the compositions of the phases of each sample were calculated, as listed in Table 2.

From the Table 2, it was found that the increase in the sintering temperature, the mullite content was increased and the quartz and corundum were reduced, as is also perceived that crystallinity decreases, indicating that the vitreous phase content has increased. 
Table 2. Phase compositions of the membranes sintered at $1100^{\circ} \mathrm{C}, 1200^{\circ} \mathrm{C}, 1300^{\circ} \mathrm{C}, 1400^{\circ} \mathrm{C}$ and $1500^{\circ} \mathrm{C}$.

\begin{tabular}{cccccc}
\hline Sample & $\mathrm{C}(\mathrm{wt} \%)$ & Corundum $(\mathrm{wt} \%)$ & Quartz (wt\%) & Mullite (wt\%) & Mica (wt\%) \\
\hline HFM $-1100^{\circ} \mathrm{C}$ & 93.62 & 77.16 & 14.76 & - & 1.7 \\
$\mathrm{HFM}-1200^{\circ} \mathrm{C}$ & 92.76 & 76.23 & 13.22 & 3.31 & - \\
$\mathrm{HFM}-1300^{\circ} \mathrm{C}$ & 85.06 & 69.93 & 8.31 & 3.56 & - \\
$\mathrm{HFM}-1400^{\circ} \mathrm{C}$ & 79.21 & 51.41 & 6.33 & 21.47 & - \\
$\mathrm{HFM}-1500^{\circ} \mathrm{C}$ & 80.01 & 13.27 & 2.31 & 64.43 & - \\
\hline
\end{tabular}

HFM - Hollow fiber membrane C - Crystallinity.

Even for higher temperatures of $1400^{\circ} \mathrm{C}$ and $1500{ }^{\circ} \mathrm{C}$ it is observed the presence of corundum and quartz, showing that these temperatures were not enough to these phases reacted, not achieving complete mullitization ${ }^{20,28-30}$. These results corroborate with research, which combined silica and alumina raw materials to obtain membranes and observed mullite phase formation at temperatures above $1300{ }^{\circ} \mathrm{C}{ }^{20,} 28^{30}$.

The Figure 3 presents the SEM images of the hollow fiber membranes.

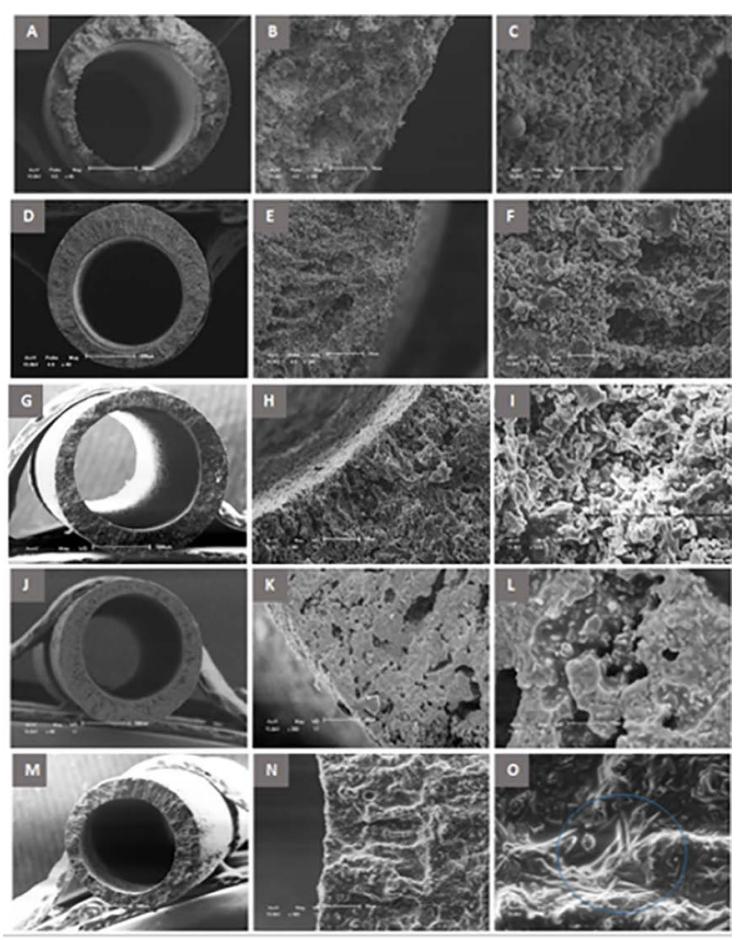

Figure 3. SEM images for membrane: $\mathrm{HFM} 1100^{\circ} \mathrm{C}$ with magnification of (a) 40x, (b) $300 \mathrm{x}$, (c) $1500 \mathrm{x}$; HFM $1200^{\circ} \mathrm{C}$ with magnification of (d) $40 \mathrm{x}$, (e) $300 \mathrm{x}$, (f) $1500 \mathrm{x}$; HFM $1300{ }^{\circ} \mathrm{C}$ with magnification of (g) $40 \mathrm{x}$, (h) $300 \mathrm{x}$, (i) $1500 \mathrm{x}$; HFM $1400^{\circ} \mathrm{C}$ with magnification of (j) $40 \mathrm{x}$, (k) $300 \mathrm{x}$, (1) $1500 \mathrm{x}$ and $\mathrm{HFM} 1500{ }^{\circ} \mathrm{C}$ with magnification of (m) 40x, (n) 300x, (o) 1500x.

From the SEM images (Figure 3) of the hollow fiber ceramic membranes, especially HFM $1100{ }^{\circ} \mathrm{C}$ and HFM $1200{ }^{\circ} \mathrm{C}$, there was an asymmetric structure consisting of a sponge-like region and by voids similar to "fingers", which is a typical structure for the hollow fibers prepared by the spinning method.
The structure similar to a "finger" originated from the inner surface until half of the cross section. The spongy structure was located in the outer region of the cross section. During the spinning process, the macroporous similar to the "fingers" were generated due to rapid exchange between solvent (NMP) and non-solvent (water) ${ }^{4,31}$. The macroporous structure is the result of interfacial instabilities between the ceramic suspension and coagulant during the phase inversion process. This phenomenon that occurs naturally can be attributed to many different mechanisms, as a result of the difference in viscosity, density and/or interfacial tension between two fluids, which destabilizes the interface during phase inversion process ${ }^{4,6,11}$.

From the cross section of the membranes, (Figures 3a and $3 b$ ) the presence of grains is visible, presenting as rounded particles $^{6}$, and pores with different sizes and preferably spherical shapes, distributed in a non-uniform way.

When the sintering temperature is increased above $1300^{\circ} \mathrm{C}$, a change in the morphological characteristic in the internal part of the membranes is detected, marked by the decrease in the number and size of pores, with a decrease in the size of the macroporous and densification of these membranes, especially at the highest temperature of $1500{ }^{\circ} \mathrm{C}$ (Figure $3 \mathrm{c}$ ). This difference in morphology is probably related to the increase in the amount of vitreous phase formed during sintering of alumina and quartzite residue. The presence of silica from quartzite that did not react with alumina, has a strong influence on the sinterability properties of mullite in hollow fiber membranes. During the sintering process, these impurities favored the bridge between the grains and densification of the membrane $\mathrm{e}^{20,28}$.

The microstructure of the sample HFM $1500^{\circ} \mathrm{C}$ (Figure 3o) have essentially mullite (needles) as the primary phase, without quartz as a crystalline phase, and it is detected the mullite covered by a vitreous phase. The excess of $\mathrm{SiO}_{2}$ can increase the densification of a sample, due to liquid phase formation during sintering ${ }^{20,28,29}$.

Figure 4 shows the apparent porosity of the hollow fiber ceramic membranes in relation to the sintering temperature.

Observing the apparent porosity of hollow fiber membranes, Figure 4, it is observed that the membranes with sintering temperature of $1100^{\circ} \mathrm{C}$ showed higher apparent porosity of $27.3 \pm 0.4 \%$, and the membranes sintered at $1400{ }^{\circ} \mathrm{C}$ have lower apparent porosity of $6.7 \pm 0.5 \%$. 


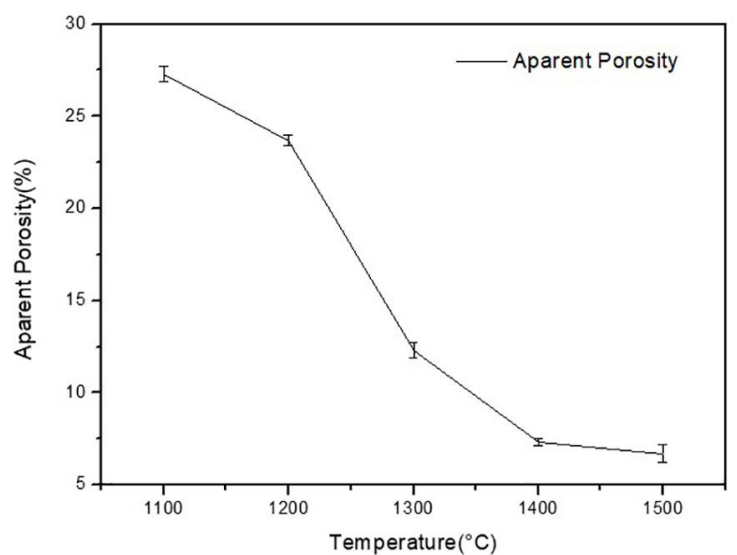

Figure 4. Apparent porosity of hollow fiber membranes at different sintering temperatures

In general, the increase in the sintering temperature caused a decrease in the apparent porosity, this behavior can be explained by the presence of liquid phase formed during heating at high temperatures, that eliminate small pores, leading to decreased porosity ${ }^{20,32}$. These results are in agreement with SEM images, Figure 3 . The porosity directly influences the permeability and mechanical resistance of membranes. More porous, the lower the resistance to the flow passing through the membrane ${ }^{32}$.

Figure 5 shows flow measurements with distilled water by hollow fiber membranes, sintered at $1100{ }^{\circ} \mathrm{C}, 1200{ }^{\circ} \mathrm{C}, 1300$ ${ }^{\circ} \mathrm{C}$ and $1400{ }^{\circ} \mathrm{C}$, with transmembrane pressure of 1.0 Bar.

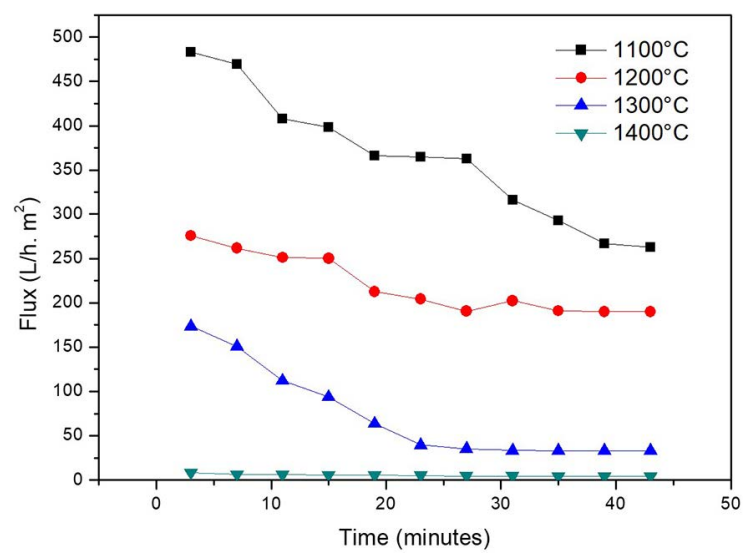

Figure 5. Water permeate flow of the hollow fiber membranes sintered at $1100{ }^{\circ} \mathrm{C}, 1200{ }^{\circ} \mathrm{C}, 1300{ }^{\circ} \mathrm{C}$ and $1400{ }^{\circ} \mathrm{C}$ and $1 \mathrm{Bar}$ of transmembrane pressure.

The permeate flow measurements with distilled water by the hollow fiber membranes, Figure 5, decreased over time until reaching a constant value from approximately 35 minutes of operation. This decay as a function of time may be associated with the hydration of the membranes ${ }^{33,34,35}$.

The membranes sintered at $1100{ }^{\circ} \mathrm{C}$ presented higher stable flow value of $263.2 \mathrm{~L} / \mathrm{h} . \mathrm{m}^{2}$, which may be associated with the greater apparent porosity value presented among the hollow fiber membranes, Figure 4. With the increase of the sintering temperature there was a decrease in porosity and, thus, a decrease in the permeate flow with distilled water by these membranes. The membranes sintered at $1400{ }^{\circ} \mathrm{C}$ showed lower flow value of $4.43 \mathrm{~L} / \mathrm{h} . \mathrm{m}^{2}$ when compared with the other membranes.

Figure 6 shows the result of flexural strength of the hollow fiber ceramic membranes sintered at temperature of $1100^{\circ} \mathrm{C}$, $1200{ }^{\circ} \mathrm{C}, 1300{ }^{\circ} \mathrm{C}$ and $1500{ }^{\circ} \mathrm{C}$, with values changing from $25 \mathrm{MPa}\left(\right.$ at $1100{ }^{\circ} \mathrm{C}$ ) to $82 \mathrm{MPa}$ (at $1500^{\circ} \mathrm{C}$ ). In this study, the flexural strength of sintered hollow fibers at $1100{ }^{\circ} \mathrm{C}$ is comparable to those of the mineral base, which are usually less than $30 \mathrm{MPa}^{31,34}$. It can be seen that flexural strength increases gradually with increased sintering temperature. This increase may be explained by neck formation and increased densification, which corroborates the reduction of open porosity, as shown in Figure 4. Flexural strength improves dramatically when the sintering temperature increases to above $1300^{\circ} \mathrm{C}$, which can be attributed to increased mullite needles and the presence of vitreous phase leaving the membrane with a structure with entangled crystals and more denser.

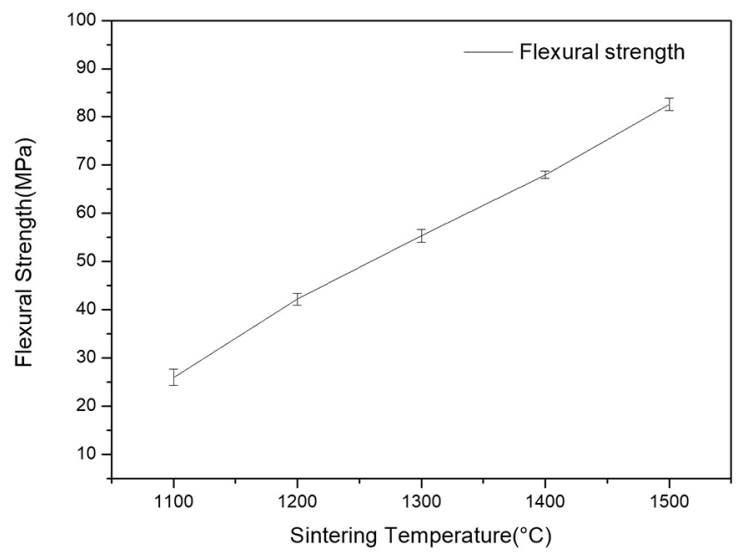

Figure 6. Flexural strength of hollow fiber membrane sintered at $1100{ }^{\circ} \mathrm{C}, 1200{ }^{\circ} \mathrm{C}, 1300^{\circ} \mathrm{C}$ and $1500^{\circ} \mathrm{C}$.

\section{Conclusions}

The results of this research indicate that it was possible to obtain hollow fiber ceramic membranes from quartzite residue and alumina. The quartzite residue and alumina presented chemical and mineralogical properties suitable for obtaining the mullite phase. The sintering temperature had a direct influence on the formation of the mullite phase, as well as in the properties of apparent porosity and water permeate flow. The higher the sintering temperature (1400 $1500^{\circ} \mathrm{C}$ ) the greater formation of the mullite phase, confirmed by the intensity and presence of mullite characteristic peaks obtained by X-ray diffraction. Regarding apparent porosity, it is perceived that the increase of the sintering temperature caused a decrease in porosity, since the higher the temperature occurred the formation of more liquid phase and, consequently, elimination of the small pores, 
leading to a decrease in porosity, which caused a decrease in the water permeate flow in the membranes. The densification of the membranes due to sintering reflected in the increase of the flexural strength, where the membranes sintered at $1500^{\circ} \mathrm{C}$ had a value of $82.6 \mathrm{MPa}$.

\section{Acknowledgements}

The authors gratefully acknowledge the financial support from CAPES, IFMG. The authors would also like to thank the laboratory of Materials Engineering, Federal University of Campina Grande for the technical support.

\section{References}

1. Lee M, Wu Z, Wang R, Li K. Micro-structured alumina hollow fibre membranes - Potential applications in wastewater treatment. Journal of Membrane Science. 2014;461:39-48.

2. Liu S, Li K, Hughes R. Preparation of porous aluminium oxide $\left(\mathrm{Al}_{2} \mathrm{O}_{3}\right)$ hollow fibre membranes by a combined phaseinversion and sintering method. Ceramics International. 2003;29(8):875-881.

3. Heidenreich S. Ceramic membranes: High filtration area packing densities improve membrane performance. Filtration + Separation. 2011;48(3):25-27.

4. Kingsbury BFK, Li K. A morphological study of ceramic hollow fibre membranes. Journal of Membrane Science. 2009;328(1-2):134-140.

5. Fang H, Gao JF, Wang HT, Chen CS. Hydrophobic porous alumina hollow fiber for water desalination via membrane distillation process. Journal of Membrane Science. 2012;403404:41-46.

6. Luiten-Olieman MWJ, Raaijmakers MJT, Winnubst L, Bor TC, Wessling M, Nijmeijer A, et al. Towards a generic method for inorganic porous hollow fibers preparation with shrinkagecontrolled small radial dimensions, applied to $\mathrm{Al}_{2} \mathrm{O}_{3}, \mathrm{Ni}$, $\mathrm{SiC}$, stainless steel, and YSZ. Journal of Membrane Science. 2012;407-408:155-163.

7. Zhang X, Fang D, Lin B, Dong Y, Meng G, Liu X. Asymmetric porous cordierite hollow fiber membrane for microfiltration. Journal of Alloys and Compounds. 2009;487(1-2):631-638.

8. Zhang JW, Fang H, Hao LY, Xu X, Chen CS. Preparation of silicon nitride hollow fibre membrane for desalination. Materials Letters. 2012;68:457-459.

9. Yang N, Tan X, Ma Z. A phase inversion/sintering process to fabricate nickel/yttria-stabilized zirconia hollow fibers as the anode support for micro-tubular solid oxide fuel cells. Journal of Power Sources. 2008;183(1):14-19.

10. Menezes RR, Fagury-Neto E, Fernandes MC, Souto PM, Kiminami RHGA. Obtenção de mulita porosa a partir da sílica da casca de arroz e do acetato de alumínio. Cerâmica. 2008;54(330):245-252.
11. Li L, Chen M, Dong Y, Dong X, Cerneaux S, Hampshire S, et al. A low-cost alumina-mullite composite hollow fiber ceramic membrane fabricated via phase-inversion and sintering method. Journal of the European Ceramic Society. 2016;36(8):2057-2066.

12. Liu Q, Xue T, Yang L, Hu X, Du H. Controllable synthesis of hierarchical porous mullite fiber network for gas filtration. Journal of the European Ceramic Society. 2016;36(7):1691-1697.

13. Lü Q, Dong X, Zhu Z, Dong Y. Environment-oriented low-cost porous mullite ceramic membrane supports fabricated from coal gangue and bauxite. Journal of Hazardous Materials. 2014;273:136-145.

14. Bai CY, Li Y, Liu ZM, Liu PW, Deng XY, Li JB, et al. Fabrication and properties of mullite-bonded porous $\mathrm{SiC}$ membrane supports using bauxite as aluminum source. Ceramics International. 2015;41(3 Pt B):4391-4400.

15. Achiou B, Elomari H, Bouazizi A, Karim A, Ouammou M, Albizane A, et al. Manufacturing of tubular ceramic microfiltration membrane based on natural pozzolan for pretreatment of seawater desalination. Desalination. 2017;419:181-187.

16. Schneider H, Komarneni S, eds. Mullite. Weinheim: WileyVCH Verlag; 2005.

17. Serra MF, Conconi MS, Gauna MR, Suárez G, Aglietti EF, Rendtorff NM. Mullite $\left(3 \mathrm{Al}_{2} \mathrm{O}_{3} \cdot 2 \mathrm{SiO}_{2}\right)$ ceramics obtained by reaction sintering of rice husk ash and alumina, phase evolution, sintering and microstructure. Journal of Asian Ceramic Societies. 2016;4(1):61-67.

18. Souto PM, Menezes RR, Kiminami RHGA. Sintering of commercial mulite powder: Effect of $\mathrm{MgO}$ dopant. Journal of Materials Processing Technology. 2009;209(1):548-553.

19. Menezes RR, Oliveira MF, Santana L, Neves GA, Ferreira HC. Utilização do resíduo do beneficiamento do caulim para a produção de corpos mulíticos. Cerâmica. 2007;53(328):388-395.

20. Guo H, Li W, Ye F. Low-cost porous mullite ceramic membrane supports fabricated from kyanite by casting and reaction sintering. Ceramics International. 2016;42(4):4819-4826.

21. Silva KR, Campos LFA, Santana LNL. Resíduo de Quartzito - Matéria-Prima Alternativa Para Ser Incorporada em Massas Utilizadas na Produção de Grés Porcelanato. Revista Eletrônica de Materiais e Processos. 2018;13(1):56-63.

22. Babisk MP, Vidal FWH, Ribeiro WS, Aguiar MC, Gadioli MCB, Vieira CMF. Incorporação de resíduo de quartzitos em cerâmica vermelha. Holos. 2012;6:169-177.

23. Carreiro MEA, Santos RC, Silva VJ, Lira HL, Neves GA, Menezes RR, Santana LNL. Resíduo de quartzito - matériaprima alternativa para uso em massas de cerâmica estrutural. Cerâmica. 2016;62(362):170-178.

24. Moreira JMS, Manhães JPVT, Holanda JNF. Reaproveitamento de resíduo de rocha ornamental proveniente do Noroeste Fluminense em cerâmica vermelha. Cerâmica. 2005;51(319):180-186.

25. Barros SVA, Marciano JEA, Ferreira HC, Menezes RR, Neves GA. Addition of quartzite residues on mortars: Analysis of the alkali aggregate reaction and the mechanical behavior. Construction and Building Materials. 2016;118:344-351. 
26. Fung YLE, Wang H. Nickel aluminate spinel reinforced ceramic hollow fibre membrane. Journal of Membrane Science. 2014;450:418-424.

27. Silva MC, Lira HL, de Freitas NL. Membrana cerâmica assimétrica à base de argila para aplicação em processos de microfiltração: influência do tempo de deposição. Cerâmica. 2014;60(355):436-442.

28. Chen G, Ge X, Wang Y, Xing W, Guo Y. Design and preparation of high permeability porous mullite support for membranes by in-situ reaction. Ceramics International. 2015;41(7):8282-8287.

29. Chen G, Qi H, Xing W, Xu N. Direct preparation of macroporous mullite supports for menbranes by in situ reaction sintering. Journal of Membrane Science. 2008;318(1-2):38-44.

30. Zhou W, Yan W, Li N, Li Y, Dai Y, Han B, et al. Preparation and characterization of mullite foam ceramics with porous struts from white clay and industrial alumina. Ceramics International. 2018;44(18):22950-22956.
31. Rui W, Zhang C, Cai C, Gu X. Effects of sintering atmospheres on properties of stainless steel porous hollow fiber membranes. Journal of Membrane Science. 2015;489:90-97.

32. Sahraoui T, Belhouchet H, Heraiz M, Brihi N, Guermat A. The effects of mechanical activation on the sintering of mullite produced from kaolin and aluminum powder. Ceramics International. 2016;42(10):12185-12193.

33. Silva FA, Lira HL, Chaves AC, Neves GA, França KB. Preparação e caracterização de membranas cerâmicas tubulares de mulita. Cerâmica. 2013;59(351):481-486.

34. Aziz MHA, Othman MHD, Hashim NA, Rahman MA, Jaafar J, Hubadillah SK, et al. Pretreated aluminium dross waste as a source of inexpensive alumina-spinel composite ceramic hollow fibre membrane for pretreatment of oily saline produced water. Ceramics International. 2019;45(2 Pt A):2069-2078.

35. Wei Z, Hou J, Zhu Z. High-aluminum fly ash recycling for fabrication of cost-effective ceramic membrane supports. Journal of Alloys and Compounds. 2016;683:474-480. 